\title{
c-Myc has Altered Expression in Canine and Feline Tumors
}

\author{
Saba Manzoor ${ }^{1, *}$, Ali Raza Awan, Abdul Wajid', Sehrish Firyal', \\ Muhammad Tayyab ${ }^{1}$, Muhammad Mansha², Asim Khalid Mahmood ${ }^{3}$, \\ Abu Saeed Hashmi ${ }^{1}$ and Muhammad Wasim ${ }^{1, *}$
}

\author{
${ }^{1}$ Institute of Biochemistry and Biotechnology, University of Veterinary and Animal \\ Sciences, Outfall Road, Lahore 5400 \\ ${ }^{2}$ Deparment of Zoology, Division of Science and Technology, University of Education, \\ Township, Lahore \\ ${ }^{3}$ Pet Center, University of Veterinary and Animal Sciences, Outfall Road, Lahore 5400
}

\section{A B S T R A C T}

Gene expression and mutation study in different cancer types of animal origin has its pivotal role in diagnosis, prognosis and comparative studies. $c-M y c$ gene was selected to study the mutation and expression profiling of different canine and feline tumors due to its predetermined role in tumor pathogenesis. A total of 52 tumor and normal samples were examined, among these, 40 canine and 12 feline samples were analyzed using Sanger sequencing method and RT-qPCR for the mutation and expression profiling of $c-M y c$ gene. The coding region of $c-M y c$ gene (exon2 and 3) did not show any variation in both species. While expression of $c-M y c$ gene was found to be up regulated in different canine $(62.5 \%$ in mammary adenocarcinoma, $75 \%$ in oral squamous cell carcinoma, $66.6 \%$ in peri-anal sac adenocarcinoma, $80 \%$ in mast cell tumor and $100 \%$ in soft tissue sarcoma) and feline $(60 \%$ in mammary adenocarcinoma and $100 \%$ in soft tissue sarcoma) tumors studied. These findings might support the established role of c-Myc in tumor pathogenesis but how this transcription factor affects the downstream targets to achieve the goal remains unanswered. Therefore, further research is desperately needed to understand the mechanism of tumor pathogenesis in animals in order to identify the molecular targets for proper cure of this ailment.
\end{abstract}
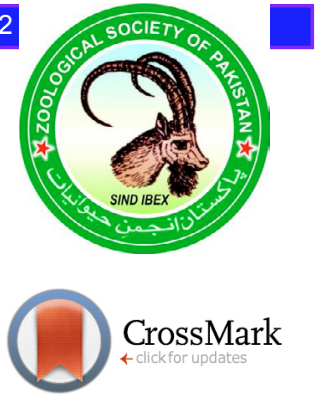

\section{INTRODUCTION}

$\mathrm{C}$ Tompanion animals such as Canis familiaris (dogs) are considered the best preclinical model for cancer and many other complex human diseases (Rowell et al., 2011). Many features make the dog an attractive model for human cancer biology research. Firstly, there is high genetic homology between the human and dog genome, compared to other animals. Secondly, dogs live in the same environment and share the similar risk factors or disease characteristics with humans (Kirkness et al., 2003). The c-Myc proto oncogene, a transcription factor located on chromosome \# 13 and F2 of dog and cat respectively, is involved in cell proliferation, cell cycle progression, differentiation and apoptosis (Meyer and Penn, 2008). c-Myc belongs to a family of related genes, N-Myc and L-Myc. Expression of N-Myc is tissue restricted and it can substitute for c-Myc in murine development (Malynn et al., 2000; Brodeur et al., 1984). The Myc (N-terminal domain)

\footnotetext{
* Corresponding authors: saba_mmg@yahoo.com; muhammad.wasim@uvas.edu.pk 0030-9923/2017/0006-2147 \$ 9.00/0

Copyright 2017 Zoological Society of Pakistan
}

contains a conserved Myc boxes (boxes I, II followed by III, IV) and a nuclear targeting sequence (Cowling and Cole, 2007). The C-terminal domain of Myc contains bHLH-Zip which remain partially unstructured till its dimerization with MAX protein (Mustata et al., 2009). Myc-MAX heterodimer bends the DNA through E-box binding motifs (5'CACGTG3'). The N-terminal domain of Myc forms complexes with transcriptional factors including TRRAP, GCN5 and TBP (Liu et al., 2003). The expression of c-Myc mRNA and protein remains very low due to absence of positive regulatory signals in normal cells (Saccani et al., 1992; Hehir et al., 1993). Under the effect of mitogenic signals or growth factors, there is an increase in the level of c-Myc which promotes the cell from $G_{0}$ to $G_{1}$ phase and this increased level lasts for approximately 30 min. c-Myc is continuously produced throughout the cell cycle until the growth factors are depleted (Mark and Sephen, 2000; Gavhane et al., 2013). The overexpression of $c-M y c$ gene mostly occurs after post-translational modification, Thr58, Ser62 mutation of coding region of c-Myc is most prevalent in the case of Burkitt lymphoma (Salghetti et al., 1999). The role of c-Myc has been studied in different cancers such as breast cancer (Gavhane et al., 2013), glioma (Wang et al., 2008), colorectal cancer 
(Smith et al., 1993) prostate cancer (Hawksworth et al., 2010) and cervical cancer (Sagawa et al., 2001).

The study aimed to find out the mutation and expression of $c-M y c$ gene in different types of canine and feline tumors and assess the possibility; c-Myc is useful marker for these malignancies.

\section{MATERIALS AND METHODS}

\section{Sample collection}

In present study, thirty eight $(n=38)$ tumors and $(n=14)$ normal tissue samples of canine and feline species were collected from University Pet center and Asim Pet Clinic, Lahore, Pakistan, from 2012 to 2015, after the proper diagnosis of tumor type and approval of ethical committee of University of Veterinary and Animal Sciences, Lahore, Pakistan.

\section{Histopathological examination}

Formalin fixed tissues were embedded in paraffin and core region of tissues ( $5 \mu \mathrm{m}$ thickness) were mounted on the glass slides and stained with Hematoxline and Eosine. Histopathological examination of tumors were performed by veterinary pathologist according to the criteria of the WHO classification of canine and feline tumors.

\section{DNA extraction}

Genomic DNA was extracted from tumor and normal healthy control tissues by using DNeasy Blood and Tissue kit (Qaigen) following manufacturer's protocol. DNA concentration was measured with Nano Drop 2000 spcectrophotometer (Thermo fisher scientific, Pittsburg PA, USA) and visualized by $0.8 \%$ agarose gel electrophoresis. All DNA samples were normalized to $50 \mathrm{ng} / \mu \mathrm{L}$ concentration.

\section{PCR amplification and sequencing}

Primers for exons $(2,3)$ were designed from intron exon boundaries of approximately $100 \mathrm{bp}$ sequence of $c-M y c$ gene by primer 3 and Net primer software (Table I) and manufactured by Advance Bioscience International. Same primers were used for both species due to $98 \%$ sequence homology for exon 2 and $93 \%$ sequence homology for exon 3. Primers were optimized with wide range of annealing temperature $\left(52-62^{\circ} \mathrm{C}\right)$ by gradient PCR and Touch down PCR along with variable concentration of $\mathrm{MgCl}_{2}$ (2.5 to $3.0 \mathrm{mM}$ ), dNTPs, primers and templet DNA in thermo cycler (Applied Bio System). PCR reaction mixture contained templet DNA $1 \mu \mathrm{L}$, Primer forward (10pmol) $0.75 \mu \mathrm{L}$, primer reverse (10pmol) $0.75 \mu \mathrm{L}, \mathrm{MgCl}_{2}(2.5 \mathrm{mM}) 2.5 \mu \mathrm{L}$, PCR buffer $(2.0 \mathrm{mM})$ $2.5 \mu \mathrm{L}$, dNTPs $(2.5 \mathrm{mM}) 2.5 \mu \mathrm{L}$, Taq polymeras $(5 \mathrm{U} \mu \mathrm{L})$
$0.5 \mu \mathrm{L}$ and DEPEC water $14.5 \mu \mathrm{L}$ to make total volume $25 \mu \mathrm{L}$. Following conditions were used in thermo cycler for amplification of desired product; First hold, initial denaturation was $95^{\circ} \mathrm{C}$ for 5 min, 25 cycles (denaturation $94^{\circ} \mathrm{C}$ for $30 \mathrm{sec}$, annealing at $58^{\circ} \mathrm{C}$ for exon 2 and $60^{\circ} \mathrm{C}$ for exon 3 for $30 \mathrm{sec}$, extension at $72^{\circ} \mathrm{C}$ for $45 \mathrm{sec}$ ), final extension $72^{\circ} \mathrm{C}$ for $10 \mathrm{~min}$ and finally hold at $4^{\circ} \mathrm{C}$. Amplified PCR products were analyzed on 1.5\% agarose gel along with $1 \mathrm{~kb}$ ladder (Fermentas, USA) the gel was stained with ethidium bromide and visualized under UVtrans illuminator (Bio Red). The PCR products were purified by ethanol precipitation and were sequenced at 3730 ABI genetic analyzer. The Bio Edit software version 7.0.5 was used to find out the novel SNP or mutation.

\section{RNA extraction and cDNA synthesis}

Total RNA was extracted and purified from tumors and normal tissues by using Gene Jet RNA purification kit (Thermo Scientific) and reverse transcribed using RevertAid first strand cDNA synthesis Kit (Themo Fisher Scientific, USA).

Table I.- Primer sequence of $c-M y c$ gene.

\begin{tabular}{llc}
\hline Exons & Primer sequences $\left(\mathbf{5}^{\prime}\right.$ - 3') & $\begin{array}{c}\text { Product size } \\
\text { (bp) }\end{array}$ \\
\hline Exon-2Fa & CCGTAACTCAAGATCGCCCC & 476 \\
Exon-2Ra & CGCTCCACATGCAGTCCT & \\
Exon-2Fb & GGACGACGAGACCTTCATCA & 499 \\
Exon-2 $\mathrm{Rb}$ & GAAAAGGCTGGGGTCAACTG & \\
Exon- 3Fa & TGGCTTGAAGGACACTGTTG & 585 \\
Exon- 3Ra & TGTTTCAACTGTTCTCGCCG & \\
Exon- 3Fb & TACATCCTGTCCGTCCAAGC & 813 \\
Exon- 3Rb & GGCCCCAGACCCATTTTAAC & \\
\hline
\end{tabular}

Table II.- RT-qPCR primers for $c-M y c$ and housekeeping gene.

\begin{tabular}{lllccc}
\hline Gene & Sp. Kit ID & $\begin{array}{c}\text { Amplicon } \\
\text { length }\end{array}$ & $\begin{array}{c}\text { Assay } \\
\text { location/exon } \\
\text { boundaries }\end{array}$ & Dye \\
\hline$c-M y c$ & Dog & $\begin{array}{l}\text { cf-02628821_- } \\
\mathrm{m} 1\end{array}$ & $126 \mathrm{bp}$ & Exon 2-3 & FAM \\
GAPDH Dog & $\begin{array}{l}\text { cat\#4331348 } \\
\text { custom } \\
\text { designed }\end{array}$ & $59 \mathrm{bp}$ & $655 \mathrm{bp}$ & VIC \\
\hline
\end{tabular}

\section{Quantitative real time PCR}

Pre designed primers and probes for $c-M y c$ gene were selected and purchased from Applied Bio System and for 
data normalization, GAPDH housekeeping gene primer was custom designed using primer express software (ABI) (Table II). The qRT-PCR reactions were carried out in 96 well plate that contained triplicates of each cDNA sample for target and housekeeping gene according to the AB1 standard protocol. The $20 \mu \mathrm{L}$ reaction mixture contained $4 \mu \mathrm{L}$ cDNA, $1 \mu \mathrm{L} 20 \mathrm{X}$ TaqMan gene expression assay, $10 \mu \mathrm{L}$ of gene expression master mix and $5 \mu \mathrm{L}$ of RNase free DEPC water. Cycling conditions were $10 \mathrm{~min}$ at $95^{\circ} \mathrm{C}$ followed by 40 cycles of $15 \mathrm{sec}$ at $95^{\circ} \mathrm{C}$ and $1 \mathrm{~min}$ at $60^{\circ} \mathrm{C}$.

Table III.- Outline of canine and feline patients' cohort.

\begin{tabular}{|c|c|}
\hline Canis familiaris $(\mathrm{n}=30)$ & \\
\hline \multicolumn{2}{|l|}{ Age } \\
\hline$=>5$ Year & $17(56.7 \%)$ \\
\hline$=<5$ Year & $13(43.3 \%)$ \\
\hline \multicolumn{2}{|l|}{ Gender } \\
\hline Male & $13(43.3 \%)$ \\
\hline Female & $17(56.7 \%)$ \\
\hline \multicolumn{2}{|l|}{ Breed } \\
\hline Germen Shepherd & $17(56.7 \%)$ \\
\hline Rottweiler & $4(13.3 \%)$ \\
\hline Golden Retriever & $3(10.0 \%)$ \\
\hline Labrador & $6(20.0 \%)$ \\
\hline \multicolumn{2}{|l|}{ Tumors } \\
\hline Mammary adenocarcinoma & $8(26.7 \%)$ \\
\hline Oral squamous cell carcinoma & $4(13.3 \%)$ \\
\hline Peri-anal sac adenocarcinoma & $3(10.0 \%)$ \\
\hline Mast cell tumor & $5(16.7 \%)$ \\
\hline Soft tissue sarcoma & $10(33.3 \%)$ \\
\hline \multicolumn{2}{|l|}{ Felis catus $(\mathrm{n}=08)$} \\
\hline \multicolumn{2}{|l|}{ Age } \\
\hline$=>5$ years & $4(50 \%)$ \\
\hline$=<5$ years & $4(50 \%)$ \\
\hline \multicolumn{2}{|l|}{ Gender } \\
\hline Female & $8(100 \%)$ \\
\hline \multicolumn{2}{|l|}{ Breed } \\
\hline Siamese & $8(100 \%)$ \\
\hline \multicolumn{2}{|l|}{ Tumors } \\
\hline Mammary adenocarcinoma & $5(62.5 \%)$ \\
\hline Soft tissue sarcoma & $3(37.5 \%)$ \\
\hline
\end{tabular}

\section{Quantification of target gene expression}

Relative expression of the target gene (c-Myc) was calculated using $\Delta \Delta \mathrm{Ct}$ method (Livak and Schmittgen, 2002). Data was presented as fold change in gene expression level in the target sample normalized to housekeeping gene and relative to the control sample. The fold change based on the delta $\mathrm{Ct}$ value was calculated using Microsoft Excel 2010. Cut off values for the fold change was set at $>1.0$ was higher and folds change value $<1.0$ was accepted lower gene expression.

\section{RESULTS AND DISCUSSION}

In the present study, incident rate of canine soft tissue sarcoma and mammary adenocarcinoma was found higher as compared to other tumors. The study tumor was most prevalent in female Germen Shepherd and Siamese breed of dogs and cats, respectively (Table III). Priester and Mantel (1971) reported that particular breed of pedigree dogs show higher incidence of particular type of tumor. The Siamese cat breed has twice the risk of developing cancer when compared to other breed of cats (Weijer et al., 1972). The same predisposition was observed in our data, since all cat cases belonged to Siamese breed.

Deregulation of $c-M y c$ gene expression in tumors and tumor cell lines have been identified by gene amplification, translocation, mutation and higher level of c-Myc RNA. The genomic DNA of tumor and healthy tissues were amplified using coding exon 2 and 3 of $c-M y c$ gene. The amplified product was subjected to DNA sequencing analysis by dideoxy chain termination method, which showed no mutation in coding exons of both species. Similarly, no rearrangement of $c-M y c$ gene was found in cutaneous B cell lymphoma (Garatti et al., 1995). c-Myc gene amplification mostly occurs late during tumor formation and is consistently observed in tumor aggressiveness, correlating with poor prognosis and distant metastasis (Singhi et al., 2012). Gain of $c-M y c$ gene was reported in $(16.7 \%)$ hyperplasia, $(9.1 \%)$ benign and (30.4\%) malignant canine mammary tumors by means of microarray (Borge et al., 2015). Similarly, Prayitno et al. (2013) reported that $9.1 \% c-M y c$ gene mutation happen in oral sequmaous cell carcinoma with HPV positive patients.

c-Myc gene expression in canine tumors

All the study tumors, showed abnormal $c-M y c$ gene expression with different fold change values. In the present study, $c-M y c$ gene was up regulated in 5/8 (62.5\%) canine mammary adenocarcinomas (specifically in C-MAM-2, C-MAM-4 and C-MAM-8 samples) with the highest fold change of 21.9, 18.2 and 14.9, respectively compared to normal mammary tissues (Fig. 1). The worth mentioning point of discussion about the $c-M y c$ gene over expression in studied tumor samples is that, all of these dogs belong to German Shepherd breed. Gavhane et al. (2013) reported that c-Myc protein expression was increased $87 \%$ in benign as well as carcinoma tumors. 


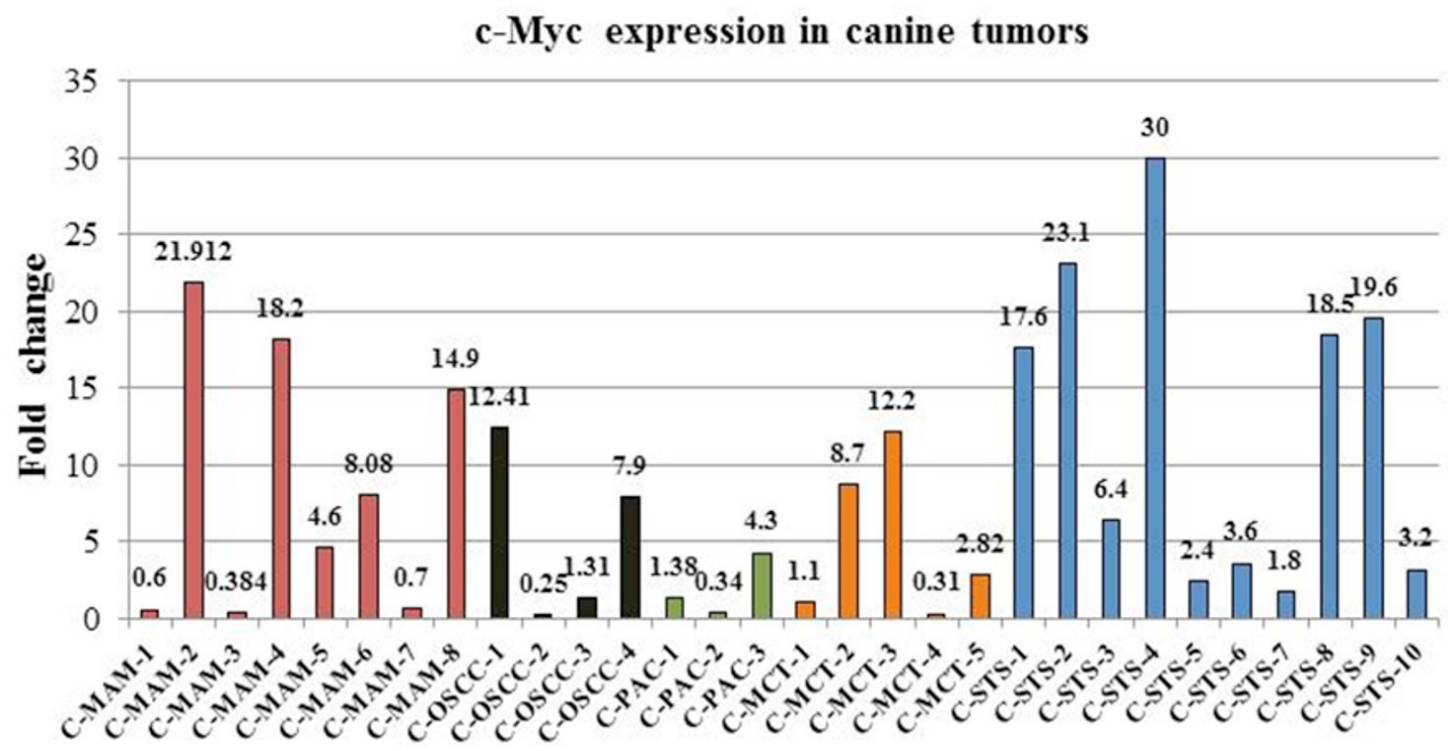

Fig. 1. Expression level of $c-M y c$ gene in canine mammary adenocarcinoma (C-MAM), oral squamous cell carcinoma (C-OSCC), peri anal sac adenocarcinoma (C-PAC), mast cell tumors(C-MCT) and soft tissue sarcoma (C-STS). Values are represented as fold change relative to normal sample (Livak method). Values $>1.0$ were considered up regulation of gene.

Similar finding was reported by Pavelic et al. (1992), Hehir et al. (1993) and Spaventi et al. (1994) that showed the increased level of c-Myc protein in $50-100 \%$ of human breast cancer patients. In canine oral squamous cell carcinoma, the up regulation of $c-M y c$ gene was observed in 3/4 (75\%) of tumor samples with the highest fold change of 12.4 and 7.9 in C-OSSC-1 and C-OSSC-4 samples, respectively (Fig. 1). Up regulation of $c-M y c$ gene was observed in $2 / 3(66.6 \%)$ peri-anal sac adenocarcinomas with a fold change of 4.3 in the F-PAC-3 samples (Fig. 1). Several studies reported the c-Myc amplification and expression in anus squamous cell carcinoma (Crook et al., 1991; Ogunbiyi et al., 1993). c-Myc gene was up regulated in $4 / 5(80 \%)$ canine mast cell tumor samples with highest fold change 8.7, 12.2 in C-MCT-2 and C-MCT-3 sample, respectively (Fig. 1). Similar finding was reported by Rodrigo et al. (2010) that showed 77.7 $\%$ occurrence and $80 \%$ expression of c-Myc mRNA in dog eyelid tumor. In another study, $93.3 \%$ expression of $c-M y c$ gene was reported at mRNA and protein level in human cutaneous melanoma (Utikal et al., 2002). All canine soft tissue sarcoma samples showed, up regulation of $c-M y c$ gene with the highest fold change of 23.1,30.0 in C-STS-2 and C-STS-4 sample, respectively (Fig. 1). A significant amplification of c-Myc was observed in canine osteosarcoma samples (Kochevar et al., 1990).

\section{c-Myc gene expression in feline tumors}

Feline mammary adenocarcinoma is third in number after hematopoietic and skin carcinoma. Sadia et al. (2016) expressed profiling of COX-2 and BRCA-1 gene in feline mammary tumors. $c-M y c$ gene was up regulated in $3 / 5(60 \%)$ of feline mammary adenocarcinoma with the highest fold change of 3.1 and 3.0 in the F-MAM-3 and F-MAM-4 samples, respectively and $100 \%$ up regulation in soft tissue sarcoma sample with highest fold change 21.8 (Fig. 2). Shon et al. (2014) reported the overexpression of $c-M y c$ gene in cutaneous angiosarcoma.

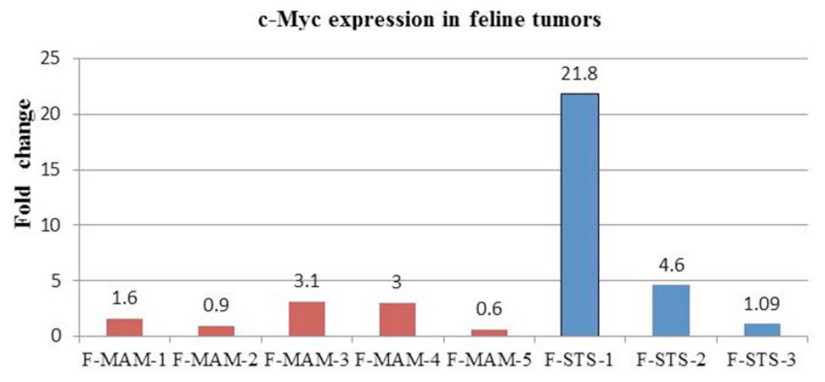

Fig. 2. Expression level of $c-M y c$ gene in feline mammary adenocarcinoma (F-MAM), soft tissue sarcoma (F-STS). Values are represented as fold change relative to normal sample (Livak method). Values $>1.0$ were considered up regulation of gene.

\section{CONCLUSION}

This is first report from this part of world in which we have observed over expression of c-Myc in most of analyzed 
canine and feline tumor samples but no polymorphism was detected in them. Enhanced expression of this transcription factor might regulate the downstream players implicated in tumor pathogenesis. These findings might support the established role of c-Myc in tumor pathogenesis but how this transcription factor affects the downstream targets to achieve the goal remains unanswered. Therefore, further research is desperately needed to understand the mechanism of tumor pathogenesis in animals in order to identify the molecular targets for proper cure of this ailment.

\section{ACKNOWLEDGEMENT}

The authors thank to the whole staff of Molecular Biology and Biotechnology Lab, Quality Operation Lab and Pet Center of UVAS, for facilitating this study and special thanks to Higher Education Commission of Pakistan for providing funds.

Statement of conflict of interest

Authors have declared no conflict of interest.

\section{REFERENCES}

Borge, K.S., Nord, S., Van, L.P., Lingjaede, O.C., Gunnes, G., Alnaes, G.I., Solvang, H.K., Luders, T., Kristensen, V.N. and Borresen-Dale, A.L., 2015. Canine mammary tumours are affected by frequent copy number aberrations, including amplification of Myc and loss of PTEN. PLoS One, 10: e0126371. https://doi.org/10.1371/journal.pone.0126371

Brodeur, G.M., Seeger, R.C., Schwab, M., Varmus, H.E. and Bishop, J.M., 1984. Amplification of N-myc in untreated human neuroblastomas correlates with advanced disease stage. Science, 224: 1121-1124. https://doi.org/10.1126/science.6719137

Cowling, V.H. and Cole, M.D., 2007. The myc transactivation domain promotes global phosphorylation of the RNA polymerase II carboxy-terminal domain independently of direct DNA binding. Mol. Cell. Biol., 27: 2059-2073. https://doi.org/10.1128/MCB.01828-06

Crook, T., Wrede, D., Tidy, J., Scholefield, J., Crawford, L. and Vousden, K., 1991. Status of c-Myc, p53 and retinoblastoma genes in human papillomavirus positive and negative squamous cell carcinomas of the anus. Oncogene, 6: 1251-1257.

Garatti, S., Roscetti, E., Trecca, D., Fracchiolla, N., Neri, A. and Berti, E., 1995. Bcl-1, Bcl-2, P53, C-Myc, and Lyt-10 analysis in cutaneous lymphomas. In: Skin cancer: Basic science, clinical research and treatment. Recent results in cancer research (eds. C. Garbe, S. Schmitz and C.E. Orfanos), Vol. 139. Springer, Berlin, Heidelberg, pp. 249-261.

Gavhane, D., Singh, A., Sood, N., Gupta, K., Rizwan, B.D.M. and Nilakanth, M., 2013. Immunolocalisation of c-Myc an oncoprotein of canine mammary tumors. Iseral J.Vet. Med., 68 : 101-105.

Hawksworth, D., Ravindranath, L., Chen, Y., Furusato, B., Sesterhenn, I., Srivastava, S. and Petrovics, G., 2010. Overexpression of c-Myc oncogene in prostate cancer predicts biochemical recurrence. Prostate Cancer Prostatic Dis., 13: 311-315. https://doi.org/10.1038/pcan.2010.31

Hehir, D.J., Mcgreal, G., Kirwan, W.O., Kealy, W. and Brady, M.P., 1993. C-Myc oncogene expression: A marker for females at risk of breast carcinoma. $J$. Surg. Oncol., 54: 207-210. https://doi.org/10.1002/ jso. 2930540402

Kirkness, E.F., Bafna, V., Halpern, A.L., Levy, S., Remington, K., Rusch, D.B., Delcher, A.L., Pop, M., Wang, W. and Fraser, C.M., 2003. The dog genome: Survey sequencing and comparative analysis. Science, 301: 1898-1903. https://doi. org/10.1126/science. 1086432

Kochevar, D., Kochevar, J. and Garrett, L., 1990. Low level amplification of c-sis and c-Myc in a spontaneous osteosarcoma model. Cancer Lett., 53: 213-222. https://doi.org/10.1016/03043835(90)90216-K

Liu. X., Tesfai, J., Evrard, Y.A, Dent, S.Y. and Martinez, E., 2003. C-Myc transformation domain recruits the human STAGA complex and requires TRRAP and GCN5 acetylase activity for transcription activation. J. biol. Chem., 278: 20405-20412. https://doi.org/10.1074/jbc.M211795200

Livak, K.J. and Schmittgen, T.D., 2001. Analysis of relative gene expression data using realtime quantitative PCR and the 2 (-delta delta c (t)) Method. Methods, 25: 402-408. https://doi. org/10.1006/meth.2001.1262

Malynn, B.A., Alboran, I.M., Hagan, R.C., Bronson, R., Davidson, L., Depinho, R. and Alt, F.W., 2000. $\mathrm{N}-\mathrm{Myc}$ can functionally replace c-myc in murine development, cellular growth, and differentiation. Genes Develop., 14: 1390-1399.

Mark, A.G. and Stephen, R.H., 2000. C-Myc proteolysis by the ubiquitin-proteasome pathway: stabilization of c-Myc in Burkitt's lymphoma cells. Mol. Cell. Biol., 20: 2423-2435. https://doi.org/10.1128/ MCB.20.7.2423-2435.2000

Meyer, N. and Penn, L.Z., 2008. Reflecting On 25 years 
with Myc. Nat. Rev. Cancer, 8: 976-990. https://doi. org/10.1038/nrc2231

Mustata, G., Follis, A.V., Hammoudeh, D.I., Metallo, S.J., Wang, H., Prochownik, E.V., Lazo, J.S. and Bahar, I., 2009. Discovery of novel myc-max heterodimer disruptors with a three-dimensional pharmacophore model. J. medic. Chem., 52: 12471250.

Ogunbiyi, O., Scholefield, J., Rogers, K., Sharp, F., Smith, J. and Polacarz, S., 1993. C-Myc oncogene expression in anal squamous neoplasia. J. clin. Pathol., 46: 23-27. https://doi.org/10.1136/ jcp.46.1.23

Pavelic, Z.P., Pavelic, K., Carter, C.P. and Pavelic, L., 1992. Heterogeneity of C-Myc expression in histologically similar infiltrating ductal carcinomas of the breast. J. Cancer Res. clin. Oncol., 118: 1622. https://doi.org/10.1007/BF01192306

Prayitno, A., Asnar, E. and Putra, S.T., 2013. The relationship between mouth squamous cell carcinoma (mscc) with $\mathrm{hpv}$ infection and the presence of P53 \& C-Myc mutation. J. Cancer Ther., 4: 939-941. https://doi.org/10.4236/jct.2013.45105

Priester, W.A. and Mantel, N., 1971. Occurrence of tumors in domestic animals. Data from 12 United States and Canadian colleges of veterinary medicine. J. natl. Cancer Inst., 47: 1333-1345.

Rodrigo,A.L., Tereza, C.C., Maria, C.R. and Alexandre, L.A., 2010. Occurrence and expression of p53 suppressor gene and c-Myc oncogene in dog eyelid tumors. Vet. Ophthalmol., 13: 69-75. https://doi. org/10.1111/j.1463-5224.2009.00753.x

Rowell, J.L., Mccarthy, D.O. and Alvarez, C.E., 2011. Dog models of naturally occurring cancer. Trends mol. Med., 17: 380-388. https://doi.org/10.1016/j. molmed.2011.02.004

Saccani, J.G, Fontanesi, M., Bombardieri, E., Gabrielli, M., Veronesi, P., Bianchi, M., Becchi, G., Bogni, A. and Tardini, A., 1992. Preliminary study on oncogene product immunohistochemistry (C-ERBB-2, C-MYC, RAS P21, EGFR) in breast pathology. Int. J. biol. Mark., 7: 35-42.

Sadia, H., Manzoor, S., Wajid, A., Tayyab, M., Firyal, S., Hashmi, A.S., Mughal, Z.U., Mehmood, A.K., Yaqub, T., Awan, A.R. and Wasim, M., 2016. Feline mammary tumors show altered COX-2 and BRCA1 expression. Pakistan J. Zool., 48: 17051714.

Sagawa, Y., Nishi, H., Isaka, K., Fujito, A. and Takayama,
M., 2001. The correlation of TERT expression with c-Myc expression in cervical cancer. Cancer Lett., 168: 45-50. https://doi.org/10.1016/S03043835(01)00501-8

Salghetti, S.E., Kim, S.Y. and Tansey, W.P., 1999. Destruction of myc by ubiquitin-mediated proteolysis: cancer-associated and transforming mutations stabilize Myc. EMBO J., 18: 717-726. https://doi.org/10.1093/emboj/18.3.717

Shon, W., Sukov, W.R., Jenkins, S.M. and Folpe, A.L., 2014. Myc amplification and overexpression in primary cutaneous angiosarcoma: A fluorescence in-situ hybridization and immunohistochemical study. Mod. Pathol., 27: 509-515. https://doi. org/10.1038/modpathol.2013.163

Singhi, A.D, Cimino-Mathews. A., Jenkins, R.B., Lan, F., Fink, S.R., Nassar, H., Vang, R., Fetting, J., Hicks, J. and Sukumar, S., 2012. Myc gene amplification is often acquired in lethal distant breast cancer metastases of unamplified primary tumors. Mod. Pathol., 25: 378-387. https://doi. org/10.1038/modpathol.2011.171

Smith, D., Myint, T. and Goh, H., 1993. Over-expression of the c-Myc proto-oncogene in colorectal carcinoma. Br. J. Cancer, 68: 407-413. https://doi. org/10.1038/bjc. 1993.350

Spaventi, R., Kamenjicki, E., Pecina, N., Grazio, S., Pavelic, J., Kusic, B., Cvrtila, D., Danilovic, Z. and Spaventi, S., 1994. Immunohistochemical detection of TGF-ALPHA, EGF-R, C-ERBB-2, CH-RAS, $\mathrm{C}-\mathrm{MYC}$, estrogen and progesterone in benign and malignant human breast lesions: A concomitant expression. In Vivo, 8: 183-189.

Utikal, J., Leiter, U., Udart, M., Kaskel, P., Peter, R.U. and Krahn, G.M., 2002. Expression of c-Myc and bcl-2 in primary and advanced cutaneous melanoma. Cancer Invest., 20: 914-921. https://doi. org/10.1081/CNV-120005904

Wang, J., Wang, H., Li, Z., Wu, Q., Lathia, J.D., Mclendon, R.E., Hjelmeland, A.B. and Rich, J.N., 2008. C-Myc is required for maintenance of glioma cancer stem cells. PLoS One, 3: e3769. https://doi. org/10.1371/journal.pone.0003769

Weijer, K, Head, K., Misdorp, W. and Hampe, J., 1972. Feline malignant mammary tumors. i. morphology and biology: Some comparisons with human and canine mammary carcinomas. J. natl. Cancer Inst., 49: 1697-1704. https://doi.org/10.1093/ jnci/49.6.1697 